\title{
Korai nyelvoktatási módszerek Japánban és Magyarországon
}

\section{Endrődy-Nagy Orsolya}

Eötvös Loránd Tudományegyetem Tanító- és Óvóképző Kar, Budapest

\begin{abstract}
A tanulmány esettanulmányként mutatja be Japán kéttannyelvüséggel kapcsolatos szabályzást, valamint a kapcsolódó árnyékoktatási intézményeket. Ezek közül kiemelten foglalkozik egy nemzetközi óvoda programjával, valamint az általa kialakított gyermekkép bemutatásával. A tanulmány különös figyelmet szentel az immersion módszernek mint a legnépszerübb japán nemzetközi óvodai ESL-angol nyelvoktatási módszernek. A tanulmány feltárja a hazai korai angol-nyelvoktatási árnyékoktatási intézményeket, ezek közül különösen a játszóházi angoltanfolyamok világát.
\end{abstract}

Kulcsszavak: kéttannyelvüség, multikulturális nevelés, japán oktatási rendszer, (immersion) belemerítés, oktatás

2000-től 2005-ig olyan szerencsés voltam, hogy Japánban tölthettem öt esztendőt. Itt japán kisgyermekeket tanítottam angolul, az immersion, azaz belemerítés módszerével. Ez alatt az időszak alatt kristályosodott ki bennem, hogy hazánkban mennyire gyerekcipőben jár az élő idegen nyelvek oktatása, hisz az élő nyelveket is a latinhoz hasonló módon, „biflázós” módszerekkel tanultuk. Szerencsére ekkoriban édesapám rengeteget utazott, így a franciát anyanyelvi közegben sajátíthattam el, akárcsak gyerekkoromtól az angolt, az ideutazó sok-sok külföldi barát segítségével, majd később Japánban az anyanyelvi kollégák segítségével csiszolhattam ismét tudásomat. Ezek a tapasztalatok mélyen belém ivódtak, és rájöttem, hogy a nyelvek ismeretén-szeretetén keresztül kultúrák kapui nyílhatnak meg mindannyiunk számára.

Az Arion programra jelentkezve a kéttannyelvűséget és a multikulturalizmust az Egyesült Királyságban, majd később a Szakértői tanulmányutak keretében Barcelonában is tanulmányoztam. 2007-ben a Brit Nagykövetség kérésére felmértem a hazai nemzetközi (kétnyelvü) angol óvodákat és a 0-8 éves korosztályt tanító iskolán kívüli nyelvtanulási lehetőségeket. Tapasztalataimat, japán és magyar angol-nyelvoktatási tapasztalataim kívánom összefoglalni ebben az tanulmányban.

\section{Elméleti alapok}

2001-et az Európai Tanács Miniszteri Bizottsága a Nyelvek Európai Évének nyilvánította (Vágó és Vass, 2006. 240. o.). Ezzel az akcióval, valamint a Lisszaboni döntés direktíváival kívánta felhívni a figyelmet a nyelvoktatás és az idegen nyelvi kompetenciaterület fontosságára. A többnyelvüség nemcsak a más-más nemzetekhez tartozó polgárok kommunikációját hivatott elősegíteni, de egymás iránti tiszteletet is kifejez. Míg a tradicionálisan többnyelvű országok (Baltikum, Svédország, Belgium) valamint a törpeállamok (Málta, Luxemburg stb.) polgárai igen nagy számban beszélnek legalább egy idegen nyelvet, addig a nagy európai országok, mint Franciaország vagy Nagy-Britannia lakosainak csupán elenyésző része. Problémás a volt keleti blokk állampolgárainak nyelvtudása is, mivel a kötelező orosz tanítási módszerei nem tudták megmutatni a nyelv igazi szépségét és sokan csupán a „krasznaja plosagy” és egyéb az akkori kiemelten fontos, teoretikus, kommunizmusra utaló kifejezésekre emlékeznek, de nem képesek például egy pohár vizet sem kérni. 
A Lisszaboni előírások és az Oktatás és Képzés 2010 munkaprogram előírásai szerint kiemelten fontos a nyelvtanítók és tanárok képzése. A Brit Nagykövetség megrendelésére 2007-ben végzett kutatásom - mely arra irányult, hogy felmérje, hazánkban mely tényező hiányzik ahhoz, hogy az angolt első idegen nyelvként szélesebb körben tanítsák - egyik tézise, hogy hazánkban hiányoznak a szakképzett, az angolt anyanyelvi szinten beszélő pedagógusok (Endrődy, 2007b. 7. o.). A 2006-2007-es tanévben indult el a kétnyelvű angol foglalkozások tartására felkészítő 120 órás kurzus az óvodapedagógus hallgatóknak az ELTE Tanító- és Óvóképző karán (Kovács, 2009. 47. o.), így ez az eredményekben még nem volt ekkor kimutatható.

Japán tartózkodásom során a japán példát közelröl láttam. A nagy nyelviskolák toborzó kampányokat szerveznek többször egy évben az angol nyelvterület (föként Ausztrália, Új-Zéland, Kanada, Nagy-Britannia) országaiban. A jelentkezőknek biztos megélhetést és folyamatos felkészítést kínálnak. A válság hatására sajnos a japán angol nyelvi piac összedőlni látszik, ám az elmúlt tíz-tizenöt esztendőben már olyannyira hatottak a fenti kampányok, hogy egyre jobban és többen tudnak és mernek beszélni angolul a japánok közül.

A 2012-es NAT kompakt előírásainak megfelelni mind mikro-, mind makroszinten csak mélyreható változásokkal lehet. A nyelvpedagógus-képzés átalakítása - Bologna nyomán - elindult, ám még mindig kevés az anyanyelvi trénerek, programok száma. Érdemes megvizsgálni néhány ajánlást és programot, mely az idegen nyelv kompetenciaterület erősítését tűzi zászlajára. Ilyen többek közt az Oktatási Minisztérium ajánlása, mely a nyelvi előkészítő évfolyamok indítását ösztönzi. Ez a program pályázatokkal és idegen nyelvi programfejlesztéssel együtt volt része a 2003-ban induló Világ-Nyelv programnak. Véleményem szerint - mint azt már korábban jeleztem - mélyreható változásokat csupán úgy tudunk elérni, ha a korai nyelvoktatást - amit az Unió kiemelten támogat - ösztönözzük, és akár már az óvodákban elindulhat intézményes szinten a nyelvoktatás. 2007-ben 20 nemzetközi, illetve kétnyelvű óvodában lehetett Budapesten játékosan elsajátítani az angol nyelvet (Endrődy, 2007b. 18. o.). Ma már egyes budai kerületek önmaguk kínálnak ennyi lehetőséget. Ezen túl számos óvodában nyelvkóstolgató foglalkozásokon vehetnek részt a gyermekek. A nemzetközi, illetve kétnyelvü óvodák büszkék rá, hogy a tőlük kikerülő 6-7 évesek nem kétnyelvű óvodába járó kortársaiknál jóval magasabb szinten beszélik az angol nyelvet. Véleményem szerint valójában nem ez a legfontosabb, hanem az, hogy merjen egy diák beszélni. Kovács Judit 2009-es tanulmányában jelzi, hogy a korai nyelvelsajátítás célja nem kizárólag a nyelvi ismeretek megszerzése, hanem a gondolkodás és kooperációs készségek, az attitüd, valamint a tanulási stratégiák fejlesztése (Kovács, 2009. 46. o.).

Fontos lenne, hogy a szülök felismerjék, hogy gyermekeik azáltal is többet fognak tudni a világról, színesebbnek fogják látni, és jobban tudnak más országok állampolgáraival kommunikálni, ha egy nyelvet nem csak 5. osztálytól és nem csak az iskolai érdemjegyért tanulnak.

Az Európai Unió-Tempus Közalapítvány által kezelt Szakértői tanulmányutak (korábbi néven Arion program) segítségével 2008-ban Nagy-Britanniában kimondottan a soknyelvű és multikulturális közeget tanulmányozhattam London egyik külvárosában, Brentben, ahol az alábbi adatok híven jelzik, mennyire indokolt az angol mint idegen nyelvi kommunikációs eszköz használata:

- 90\%-a a diákoknak etnikai kisebbség tagja

- $10 \%$ európai brit

- $16 \%$ ázsiai brit indiai örökséggel

- $15 \%$ brit afrikai örökséggel 
- $11 \%$ brit karibi örökséggel

- $6 \%$ ázsiai brit pakisztáni örökséggel

- $1 \%$ vándorló, cirkuszcsaládok gyermekei, cigányok

- $8 \%$ menekült

Nyelvek Brentben:

- A diákok 57\% -a második nyelvként beszéli az angolt csupán

- Körülbelül 130 féle nyelven beszélnek a Brentben élő családok gyermekei

Nagy-Britannia Oktatási Minisztériuma az alábbi értékek, alaptézisek mentén építi fel az angol mint idegen nyelvi kommunikációs kompetenciaterület nemzeti alaptantervét (Primary, 2007):

1. Minden gyermek kompetens tanuló születésétöl fogva, és mint ilyen, rugalmas, magabiztos, hozzáértő és bizakodó.

2. Egy kapcsolatban, ami a szereteten és biztonságon alapul, a gyermek képes arra, hogy megtanulja, hogyan legyen erős és független (ilyenek a szülők, vagy más kulcsszereplők, pl. tanárok).

3. A motiváló környezet kulcsszerepet játszik, segíti a gyermek fejlődését és tanulmányait.

4. A gyermekek különböző módokon fedezik fel a világot. A megismerés és a tanulás is változatos. Minden nemzetiség, kisebbség egyaránt fontos a fejlődés és a tanulás szempontjából. (Ez utolsó mondat azért is fontos, mert egyenrangúnak tekinti a tanult idegen nyelvet az anyanyelvvel.)

Az angolt második nyelvként, ESL (English as a Second Language) tanulja a brenti diákok több mint fele az alábbi kihívások mentén (The Early, 2007):

- A gyermek egyénisége: fejlődés, inkluzív oktatás, biztonság, egészség

- Pozitív kapcsolatok: egymás tisztelete, a szülők mint partnerek, a tanulás támogatása, a kulcsszemély

- Megfelelő környezet: megfigyelés, értékelés, tervezés, minden gyermek segítése, tanulási környezet, szélesebb kontextus

- Tanulás és fejlődés: játék és felfedezés, aktív tanulás, kreativitás és kritikai gondolkodás, a tanulás és fejlődés területei (lásd 1. ábra)

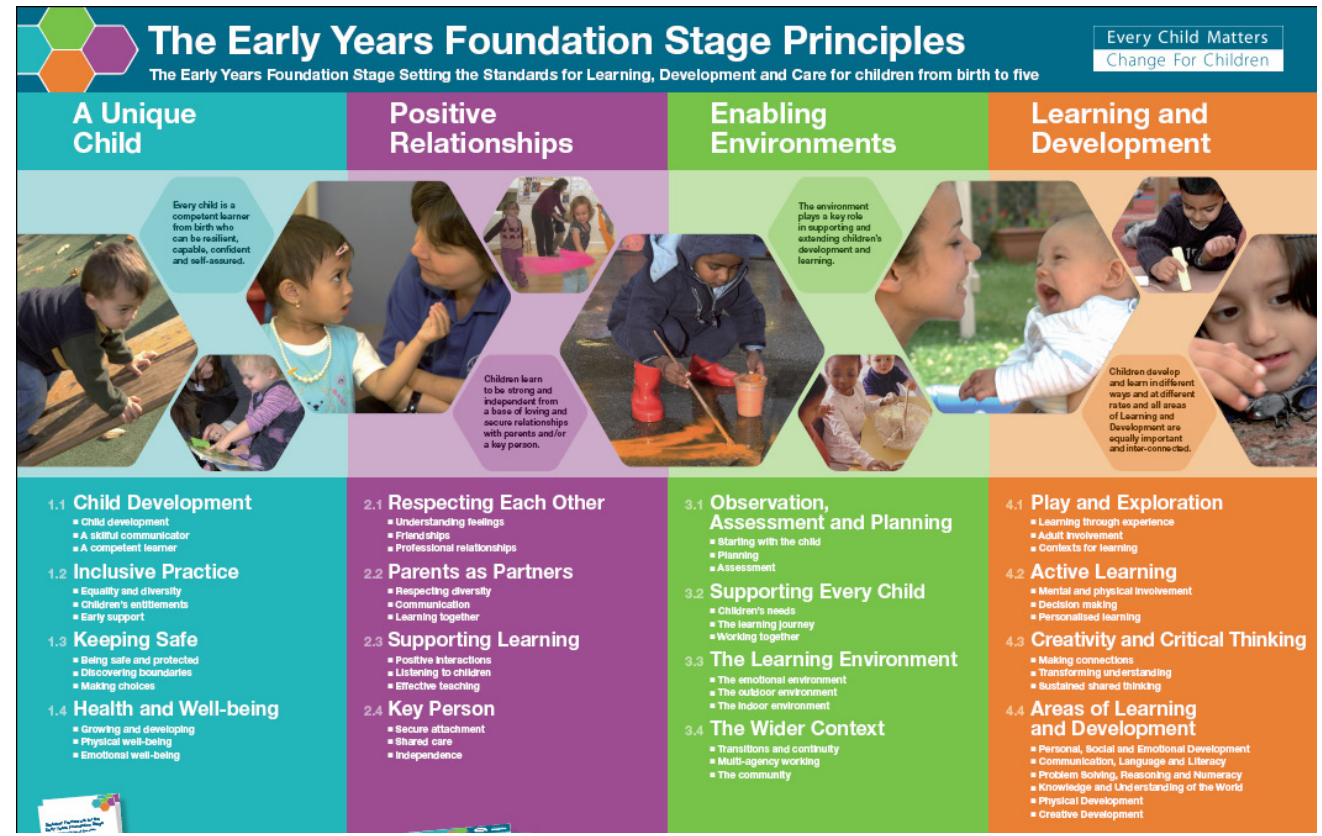

1. ábra: Az alapozó szakasz előírásai (The Early Years, 2007) 
A tanulás és fejlődés (Primary, 2007) az alaptanterv értelmezésében az alábbi tézisek figyelembevételével valósul meg a nyelvoktatásban is:

- A játék tükrözi a gyermek érdeklődését.

- Játék közben tanulnak legintenzívebben.

- A kortársakkal való játék elsődleges a fejlődés szempontjából.

- A kihívások során aktívan tanulnak.

- Az aktív tanulás mások bevonásával, tárgyak segítségével történik. Fontosak a különféle rendezvények is ebből a szempontból.

- A felnőttek segítségével sajátítják el a kritikai gondolkodás képességét.

Mindezen előírások ismertetését az indokolja, hogy Japánban töltött éveim alatt hasonló elveket figyeltem meg magam is az óvodásaimnál. Ezeket a tapasztalataimat kívánom a következő fejezetekben összefoglalni, némi kulturális-történeti bevezető után.

\section{Japán - belemerítés mint a nyelvtanulás kulcsa}

A japán iskolarendszer 6-tól 15 éves korig tartó tankötelezettség időszakát és az oktatási rendszer felépítését az 2 . ábra szemlélteti.
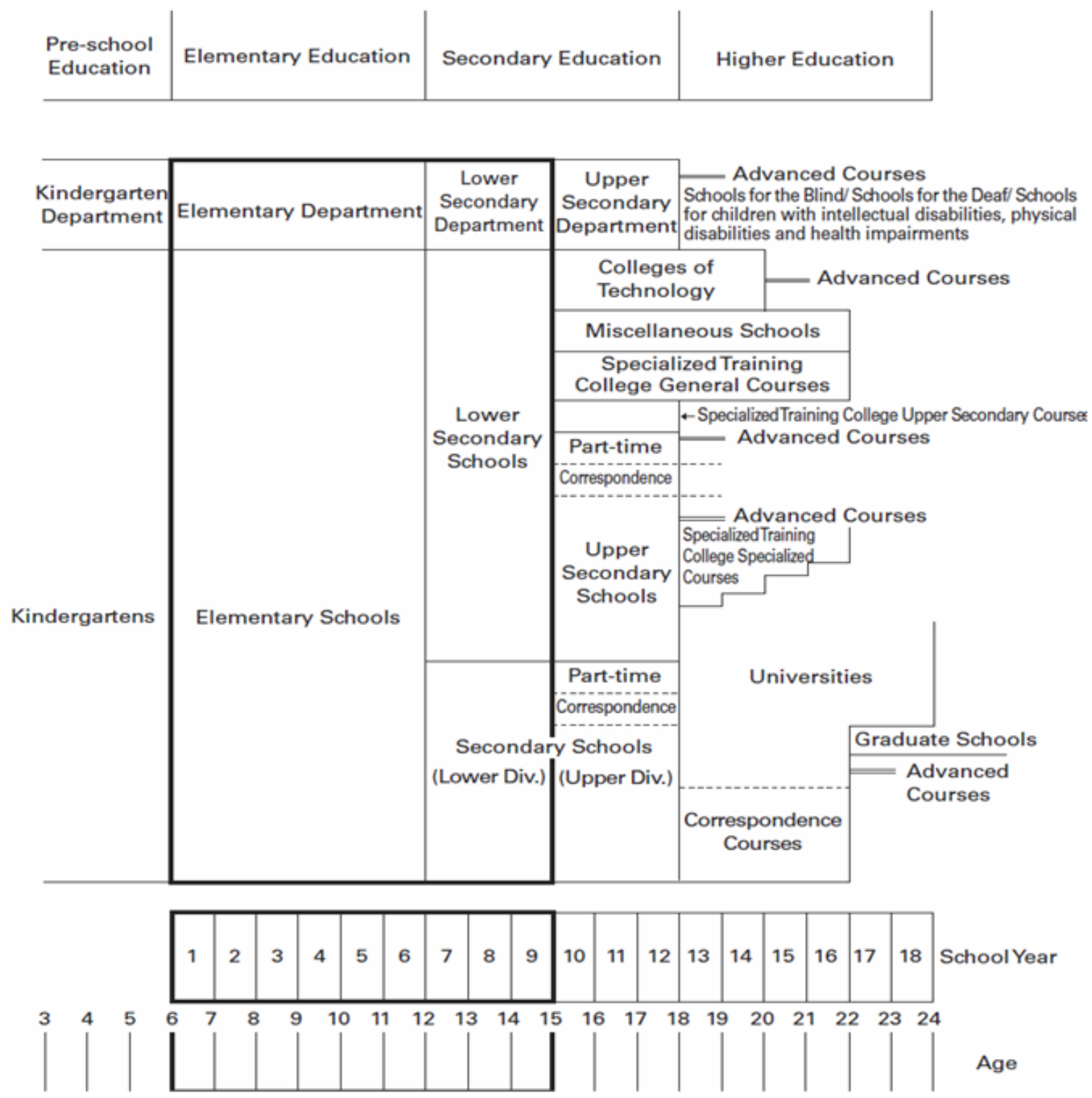

2. ábra: A japán oktatási rendszer áttekintő képe 
Jól látható, hogy az elemi oktatás első 6 éves időszakát a kétszer 3 éves alsó és felső középiskola követi. A tankötelezettséget követően a diákoknak számos felsőfokú szakképzési és felsőoktatási továbbtanulási lehetősége van. Mi a helyzet a tankötelezettséget megelőzően? Kielégítőnek tartják-e a japánok az intézményes közoktatási kereteket? Vegyük szemügyre ezeket a kérdéseket!

A gyermekeknek iskoláskorukat megelőzően két lehetősége van: a bölcsőde megfelelője a hoikuen, mely hosszú nyitvatartási idővel várja a dolgozó édesanyák gyermekeit, és lehetőség van arra is, hogy ebben az intézményben maradjanak egészen 6 éves korukig. A yochien alapvetően az óvoda megfelelője, azzal a különbséggel, hogy csupán délután 2-ig van nyitva, ami után a szülök általában hazaviszik a gyermekeket, kivéve, ha az óvoda szervez valamilyen különórát, illetve biztosít felügyeletet, de ebben az esetben is 4 órakor bezár az intézmény. Mindebből következően jól érzékeljük, hogy az ún. árnyékoktatás ${ }^{1}$ virágzó szolgáltatási paradicsomot jelent a gyermekek számára.

Az árnyékoktatás legfőbb intézménye az a kiterjedt előkészítőiskola-hálózat, melyet juku-ként szokás japánul említeni. Japán és Kelet-Ázsia más részein ez a típusú intézmény virágzik (Numata, 2005. 261. o.). A 2007-es nemzeti felmérés adatai mutatják, hogy az általános iskola 1. osztályában 15,9\%, a 3. osztályos alsó középiskolások (15 évesek) közül 65,2\% százalék vesz igénybe ilyen intézményt tanulmányai során, ehhez hozzájön még esetükben a házi korrepetálás, melyet 6,8\%-uk vesz igénybe (Bray, 2013. 19. o.). Tapasztalataim szerint az óvodásoknak is lehetőségük van ehhez hasonló ún. iskolaelőkészítő foglalkozásokra. (Egy 3 éves kisfiú például minden nap elmesélte, hogy előző nap milyen betűket (rómadzsikat, angol betűket) gyakoroltak a jukuban, miután az én óvodámból távozott.)

A japán óvodák a hazaihoz hasonlóan a gyermekközpontúságukról híresek és arról az elvről, melyet Tobin és társai (2009. 108. o.) könyvükben úgy neveznek, hogy kodomo-rashi, azaz gyermekiesség, a gyermekek lehetősége arra, hogy gyermekségüket megéljék szabad játék formájában. Tobin és kutatótársai megállapítása szerint a legfőbb - óvodában elsajátítandó - értékek ugyanakkor az empátia, alkalmazkodóképesség és a szocialitás, a társakkal való együttműködés (Tobin, Hsueh és Karasawa, 2009. 224. o.). Ezt az attitüdöt japánul amae-nek, azaz gyermeki engedelmességnek is szokás nevezni (Doi, 1981. 51. o.; Numata, 2005. 260. o.). Érdekes, európai szemmel ellentmondásnak tűnő következtetés húzódik meg e mögött a két tétel mögött, mégpedig, hogy a gyermek korlátok közé szorítva élje meg gyermekségét. Igen ám, de gondoljunk arra, hogy Ázsia több országához hasonlóan a népsűrűség igen magas, így már csak emiatt is fontos, hogy a gyermekek korán elsajátítsák az alkalmazkodás legmagasabb fokát. Ehhez társul a konfuciánus világlátás, mely szerint az alázat és egymás tiszteletben tartása kiemelkedően fontos.

A rövid japán óvodai áttekintés után feltehetjük azt a kérdést, hogy miért olyan fontos az angol nyelv minél korábbi elsajátítása a japánok szerint. Válaszomat történelmi és gazdasági síkon tudom indokolni. Japánban az ún. Edo-korszakban 1603-1867-ig a határok zárva voltak, (Numata, 2005. 243. o.) így a 20. században fokozatosan, majd az atombombák ledobása után az amerikai kultúra szó szerint berobbant a japán gondolkodásba, és az amerikai katonák jelenléte miatt megnövelte a velük történő kommunikációra való igényt. Japánra erőteljesen hatottak az UNESCO előírásai is, hiszen

\footnotetext{
1 Árnyékoktatás alatt a brayi terminológiával élve a magán tutori jellegű iskolán kívüli oktatási-nevelési intézményeket értem (Bray, 2013. 18.)..
} 
világháborús vesztesként igyekezett minél jobban megfelelni azoknak. Az előírások közt szerepelt, hogy mindent meg kell tenni annak érdekében, hogy más országok kultúráját baráti módokon megismerhessék (Fujikane, 2006. 135. o.). Később a gazdasági forradalom elindulása szintén növelte az angol területekről és területekre történő migrációt. A 60-es évektől fokozatosan jöttek létre angol nyelvoktató iskolahálózatok (ECC, 1962, AEON, Geos, 1973, NOVA, 1981). Ezek az iskolák Anglia, Ausztrália, Új-Zéland és az észak-amerikai kontinens országaiban tartanak angol nyelvtanár-toborzást. Azonban a fokozatosan begyűrűző gazdasági lassulás majd válság menekülésre, illetve összeolvadásra késztetett számos iskolahálózatot, hazatelepülésre native, azaz anyanyelvi angoltanárt, így jelenleg egyre több iskola alkalmaz már szívesen európai angolnyelv-tanárokat is, akiknek a feladata nemcsak a nyelvtan és a szép kiejtés megtanítása, hanem az amerikai, brit kultúra után más európai kultúrák megismertetése is. Így kerülhettem én is Japánba és taníthattam ott öt évig különböző intézményi keretek közt angolt, illetve európai kulturális szokásokat. Márkus Éva 2009-es tanulmányában kifejti, hogy a kommunikáció miért nem pusztán információcserét jelent, hanem ezen túlmutatóan a tőlünk eltérő kultúrából érkező, idegen nyelvet beszélő életfelfogását, világnézetét és az adott nyelv kulturális szokásait is megismerheti a nyelvet tanuló (Márkus, 2009. 55. o.). Ezen téziseket tapasztalhattam meg élőben Japánban.

Tekintsük át, hogy milyen általam megismert keretek közt lehet angolul tanulni Japánban a korai gyermekkor idején!

- juku, azaz előkészítő iskola (3 éves kortól)

- yochien (3 éves kortól), hoikuen (általában 3-5 hónapos kortól), azaz óvoda és bölcsőde (kagai-kanai azaz foglalkozás keretében és külön óraként - a legfiatalabb korosztály, amelynek angol foglalkozást tartottam, 1-2 éves volt

- bevásárlóközpont, játékbolt, gyorsétterem (játékos foglalkozás egy szolgáltató szervezésében előre meghatározott rendszeres időpontban) - féléves kortól

- international preschools, azaz nemzetközi óvodák

- "házi tanító-babysitter" - magántanár látogat egyeztetett időpontban a gyermekhez (akár már születéstől)

- nyári táborok (3 éves kortól!)

A továbbiakban a fent felsorolt formák módszertani sajátosságait kívánom összefoglalni saját tapasztalataim alapján, különös figyelmet szentelve a nemzetközi óvodáknak egy konkrét óvoda programjának elemzésén keresztül.

A juku, azaz előkészítő iskola látogatása különösen az iskolás korosztályra jellemző, hasonló, mint egy napközi, a gyermekeknek lehetőségük van a házi feladatok megírására és ezen túl további gyakorlásra. A tantermi elrendezés tapasztalataim szerint frontális, de a tanár - akinek nem feltétlenül van tanári végzettsége - egyénileg, differenciáltan foglalkozik a diákokkal. A jukuban az írás gyakoroltatása mellett főként a számtani és angol nyelvi ismeretekre fókuszálnak (Endrődy, 2007a. 11. o.). Mivel a kanjik, azaz japán írásjelek elsajátítása a pontos másoláson és gyakorláson alapszik, elöszeretettel ismételtetnek és íratnak le példamondatokat többször a tanárok az angol nyelv gyakorlásaként is. A japán oktatási rendszer fő kritikájáról ír részletesen Győri Gordon János, ezek közül néhány: nem nevel kreativitásra, túlságosan tantárgycentrikus (Győri, 20092). Véleményem szerint ez okozza azt a jelenséget, hogy a japánok sokkal magasabb szintü angol nyelvismeretről tesznek tanúbizonyságot írásban, mint szóban, valamint ez okozza azt a jelenséget is, hogy az anyanyelvi nyelvtanároknak inkább a szóbeli produkcióra kell fókuszálni. Külön kifejezés van az

\footnotetext{
2 www.ofi.hu/tudastar/oktatas-harmadik-atfogo\#1
} 
angol nyelvtanításban a szóbeli-kommunikációs fejlesztésre: eikaiwa - ami nem más, mint angol kommunikációs szóbeli óra, sőt, vannak kimondott eikawa-iskolák is! Ilyenek a már fent említett láncok is.

A nyelvi táborokról jelen keretek között nem szeretnék bővebben szót ejteni, érdekesség, hogy már 3 éves gyermeket is fogadnak, abban az esetben is, ha ott lehet aludni.

Trentinné (2009) metaforakutatásaiban árnyalja a tanulók angol nyelv tanulásához kapcsolódó szivacs-metaforát. Tapasztalataim szerint a japánok többsége tisztában van azzal a ténnyel az idegennyelv-tudás kapcsán, hogy minél korábban kezdődik, annál hatékonyabb. Az elvet alkalmazva akár már újszülöttjük mellé is fogadnak angol „,házitanító-babysitter”-eket, vagy játszócsoportokba járnak a különböző már említett áruházi, játékbolti vagy gyorséttermi angol foglalkozásokra.

Mivel igen alacsony azon óvónők és bölcsődei gondozók száma, akik megfelelő végzettséggel rendelkeznek, ám a szülői igény hatalmas a délelőtti angol szakfoglalkozások és délutáni elfoglaltságot jelentő óvodai (yochien) és bölcsődei (hoikuen) foglalkozásokra, angoltanárok kiközvetítésére számos cég specializálódott Japánban. A foglalkozások és az óvodai különórák módszertana eltért egymástól. Délelőttönként került sor a foglalkozásokra. A kiküldő cég munkatársaként minden nap más és más óvodába látogattam el. llyenkor egy-egy csoporttal foglalkoztam egy japán anyanyelvű angoltanár és a csoport óvónője segítségével. A csoportok óvónői a gyermekek közé állva részt vettek a foglalkozásokon, a japán anyanyelvű angoltanárok pedig, ha szükséges volt, fegyelmeztek és lefordították a feladatokat. Az új szavakat, meséket minden esetben fordították. Egy-egy foglalkozás 35-45 perces volt, korosztályi bontásban kiscsoporttól nagycsoportig 5-5 perccel növelve a foglalkozás hosszát. Egy-egy csoportban a japán átlagnak megfelelően 32-35 gyermek volt. A foglalkozások módszertanára jellemző még a Flashcardok használata, melyeket a kiküldő cég grafikusa tervezett, minden hónapban részletes leírást kaptunk arról, hogy lehet az adott havi adagot kreatívan használni. Minden szókincsbővítő elemnél például a következő ritmikus formulát alkalmaztuk: például Lion (oroszlán) esetén: „What's this? What's this? It's a lion. It's a lion." A kérdést az angolos pedagógus tette fel, a választ először a japán angolszakos mondta, aztán ezt a kérdés-feleletet még kétszer megismételtük, ekkor már kórusban a gyermekekkel. A módszer értelmében ugyanis mindent 3-szor kell ismételni, és minden erre a hármasságra épült. A minden hónap elején kiküldött elméleti útmutató részletesen kifejtette, hogy a gyermekek első alkalommal a bemutatatáskor megfigyelik a játékot, szót, kártyát stb., második alkalommal megértik, harmadik alkalommal pedig képesek kimondani. Ezzel az ismételgetős, felelgetős módszerrel az órák felépítésénél és az egymásra épülésénél is találkozunk, az új szókincsre a következő alkalommal játék épül, mely a megértést segíti, harmadik alkalommal pedig olyan kommunikatív játék, amikor a diákoknak kell felismerni és kimondani a képen látható alakot. PI. Lion esetén: 1. alkalommal a What's this? - már ismertetett bemutató, 2. alkalommal Lion-game, azaz állatkártyákat mutatott a tanár és megkergette a diákokat, ha a felmutatott állat oroszlán volt. 3. alkalommal pedig Missing-game, azaz eldug a tanár egy kártyát az előzőekben bemutatottak közül, míg a diákok behunyják szemüket, és ki kell találni, mi hiányzik, és hangosan ki kell mondani (lásd 1. melléklet).

A délutáni különórák keretében a kiscsoportos, középsős és nagycsoportos gyermekek vegyes életkori csoportban voltak, körülbelül 8-10 fő csoportonként. Már a legkisebbek is munkafüzetben dolgoztak nagyjából 15-20 percig, majd ezt követte egy 25-30 perces játékos, szóbeli kommunikációra és a fenti módszertani alapokra építő foglalkozás. A foglalkozásokat minden héten megtartják, de az ún. anyanyelvi angoltanárok csak kéthetente látogattak el egy-egy csoporthoz. Elég nagy nehézséget okozott, hogy egy nap akár 3-4 különböző helyre is kellett utazni, és az óvodák akár egy óra járásra helyezkedtek el egymástól. 
A hazai kutatások (Nikolov, 2004. 17. o.; Kovács, 2009. 46. o.) egybehangzó véleménye, hogy a kisgyerekek idegen nyelvi fejlődésének üteme jóval lassúbb, mint a serdülőké vagy a fiatal felnőtteké. A korai ismerkedés a nyelvvel a nyelvi iránti fogékonyságban és folyékonyságban, a verbális készségekben nyilvánulhatnak meg. Kedvezően hathat az attitüdökre, nyitottságra, önbizalomra, illetve motiváló hatású lehet további nyelvek elsajátítására. Ezen állításokra kiváló példát jelentett a fenti utazótanári tapasztalat és a későbbi nemzetközi óvodai tapasztalatom, melyet az alábbiakban képek segítségével kívánok bemutatni.

A nemzetközi óvodában gyakran tapasztaltam azt a tényt, ami a De Houwer-féle kutatások is megerősítenek, hogy a két nyelvet tanuló gyermekek némelyike olyan perióduson megy keresztül, amelyben keveri a két nyelvet, de ez valójában nem a zavartság jele, hanem általában olyan helyzetekben fordul elö, amikor a gyermek tudja, hogy beszélgetőpartnere mindkét nyelvet megérti, vagyis a szociális kontextustól függően alkalmazza a nyelveket (De Houwer, 2009). Aimi, egy 3 éves kislány például a szülei legnagyobb ijedségére két hónapig sem japánul, sem angolul nem volt hajlandó megszólalni azután egy hónappal, hogy beíratták hozzánk. Három hónappal az óvodába lépés után megértette a helyzetet és képes volt ki is fejezni, hogy csak angolul beszél az óvodában. Ha anyukája japánul kérdezte a napi eseményekről, nem válaszolt neki, csak azután, hogy kiléptek az ajtón. Ettől kezdve már csak angolul szólalt meg az óvodában, ha nem tudott valamit elmondani, körülírta.

Létezik egy olyan életkor, egy minimális kezdési időpont, amely nagyon valószínủvé teszi egy idegen nyelv anyanyelvi szintű elsajátítását. Ez a kor 5 és 9 év közöttre datálódik, de 15 éves kor alatt is jó esély van a hatékony nyelvtanulásra (Seliger, Krashen és Ladefoged, 1975. 220. o.). Mint a továbbiakban látható, a nemzetközi óvodába járó tanítványaim nagy része 3-4 éves volt, de én is azt tapasztaltam, hogy a legoptimálisabb, leglátványosabb fejlődést az 5 éves korosztálynál értük el.

Az alább bemutatott nemzetközi óvoda egynyelvű angol és valóban nemzetközi, ugyanis a diákok körülbelül fele japán, a másik fele más anyanyelvű volt, például pakisztáni, iráni, brazil, koreai, német, thai. A pedagógusok ismerik azt a kettősséget, mely a kétkultúrájúság és a kétnyelvű diákok jellemzője, ez gyakran együtt jár a törékeny egyensúllyal (Kitzinger, 2009. 195. o.), mely a hibrid identitás velejárója. Ennek fényében érthető, hogy az óvodában nagy hangsúlyt kellett helyeznünk a sokféle kultúra, vallás, népszokás megismertetésére. Ezen rövid felvezetö után következzen az óvoda bemutatása.

\subsection{A Blue dolphins-módszer}

Az óvoda, melyben tanítottam, egy japán alapítású multinacionális vállalat fenntartásában müködik. Egy ún. ernyőszervezetet képeznek iskolái, óvodái. Az árnyékoktatás és az intézményes oktatás területén is vannak érdekeltségei. Tart fent egy juku-hálózatot, könyvkiadót, szakértői intézetet, ausztrál és új-zélandi japán iskolákat és egy nemzetközi óvodai iskola-előkészítő láncot. Ennek Oszaka, Kobe és Tokió mellett más területeken is vannak tagjai. A hálózat ugyanazzal az oktatási programmal és küldetésnyilatkozattal rendelkezik. A küldetésnyilatkozat egy speciális gyermekképet konstruált, mely nemzetközi atmoszférát sugároz. Gyermekképük kulcsfogalmai a szeretet, barátságos gyermekközpontú környezet, önbizalom-építés és magabiztosság az angol nyelv elsajátításában. A diákok biztonságban érezhetik magukat, és közeli kapcsolatot építhetnek ki a tanárokkal és diáktársaikkal. Mindenki odafigyel az egyéni adottságokra. Bár nagy nyomás nehezedik a diákokra, szeretnek óvodába járni. (A küldetésnyilatkozatot egy következő tanulmányban szeretném dokumentumelemzésnek alávetve elemezni.) 
Kicsit közelebbről áttekintve: a módszer a belemerítés. A tanulók másfél éves kortól járhattak az óvodába, mely délelőtti (10-14 óráig) és délutáni (16-17.30 óráig) kurzusokat kínált a hét hat napján. Lehetőség van ún. intenzív kurzusra, mely öt napon, hétfőtől péntekig biztosít lehetőséget az óvodába járásra, illetve lehetőség van a naponkénti megjelenésre keddtől szombatig. A délelőtti foglalkozások óvodaszerüen müködnek, délután pedig inkább a különórákhoz sorolhatók, hisz a gyermekek a hagyományos japán óvoda után érkeznek, és a jukuhoz hasonló keretek közt tanulhatnak.

\subsubsection{Napirend}

A délelőtt a honlap szerint így alakul jelenleg is, és az én kint tartózkodásom alatt is így alakult (www.blue-dolphins.net):

Reggel:

9.40-10.00 Érkezés, szabad játék

10.00-10.15 Zenés-táncos bemelegítő

10.15-10.45 Circle time, Phonics

10.45-11.00 Mosdóhasználat

11.00-11.15 Tízórai

11.15-11.45 Craft time

11.45-12.15 Topic

12.15-12.45 Meseolvasás, DVD-nézés

12.45-13.00 Előkészülés az ebédhez

13.00-13.40 Ebéd

13.40-14.00 Szabad játék, búcsúzás

Délután:

15.30-16.00 Érkezés, szabad játék

16.00-16.15 Zenés-táncos bemelegítő

16.15-16.30 Circle time, Topic

16.30-16.45 Uzsonna

16.45-17.00 Craft time

17.00-17.15 Írás, számolás, feladatlapok, phonics

17.15-17.30 Meseolvasás, olvasás gyakorlása

\subsubsection{Módszertan}

- Belemerítés-módszer gyakori alkalmazása a beszélgetés és vita módszerének

- Circle time: bemutatkozás, érzelmek, időjárás, idő, színek, formák, számolás játékos elsajátítása

- Phonics: ABC, hangkészlet elsajátítása

- Topic: A tervezés során az összes iskola képviselöje összegyülik havonta egyszer a központban, vagy az egyik iskolában és három hónapra előre eldönti a témákat, illetve a következő hónapra játékokat beszél meg, két hónappal előre pedig részletesen kidolgozza az elsajátítandó szókészletet, mondatokat, kommunikációt, amire fókuszálni kell. Félévente egyszer minden tanár tréningen vesz részt, ahol újabb és újabb játékokat, módszertani ötleteket lehet elsajátítani, valamint a japán gondolkodásmód elemeibe, neveléselméleti hátterébe avatják be felkészült egyetemi tanárok, trénerek. 
- Étkezések közben zenét hallgatnak a gyermekek, az iskola filozófiája, hogy a zenehallgatás segíti az étkezést és közben az európai kultúra zenei gyöngyszemeit, például Mozart remekműveit lehet megismertetni a gyermekekkel.

- DVD-nézéskor japán és amerikai mesefilmeket néznek a gyermekek angolul, csupa olyan mesefilmet, melyet otthon japánul már nagy valószínüséggel láttak, ezzel is segítve a megértést, a passzív szókincsbővítést.

- Jó idő esetén a játszótéren szabadjáték és játékos foglalkozások váltják egymást például parachute-games (ejtőernyős játékok).

- Az írás-olvasás előkészítése két éves kortól folyamatos, eleinte ún. tracing sheets-et, azaz összekötést, egyenes vonalhúzást, egyszerü formák satírozását, majd minden héten egy betű megismerését tüztük ki célul. Én ezt úgy valósítottam meg, hogy a tanteremben több helyre feltűztem a falra a betủket A3-as méretben. Meg kellett találnia a kisebbeknek, a középsős korosztálynak a nagy kapitális, a nagycsoportosoknak a kis kapitális betűket színezni, összekötni, majd írni.

- Félévente minden szülő értékelést kap gyermekéről, hogy mit sajátított el az elmúlt hónapokban. Ennek az értékelésnek komoly adminisztratív vonzatai vannak, melyhez különböző kiértékelő lapokon kap segítséget minden tanár. (lásd 2. melléklet) Az olvasást négy éves kortól tanítja az iskola a brit módszertan alapján szótagoló olvasással.

Ezután a módszertani leírás alapján nézzünk röviden néhány fotót (EndrődyNagy, 2011), hisz a képek segítségünkre lehetnek abban, hogy nevelési szituációkat bemutassanak, megtörve ezzel a csendet, úgy is, mint az adott korszak vagy térség nevelési elveivel és gyakorlatával kapcsolatos üzenet hordozói (Depaepe és Henkens, 2000. 11. o.). Sontag szerint pedig: „Minden fénykép többszörös jelentést hordoz; fényképen látni valamit csakugyan annyi, mint szembetalálkozni a lappangó valósággal" (Sontag, 2007. 38. o.). A képelemzéshez Mitzner és Pillarcyk (2005) vizuális antropológiai módszerét kívánom segítségül hívni. Minden fotóról csak az elemzéssel kibomló célt kívánom bemutatni.

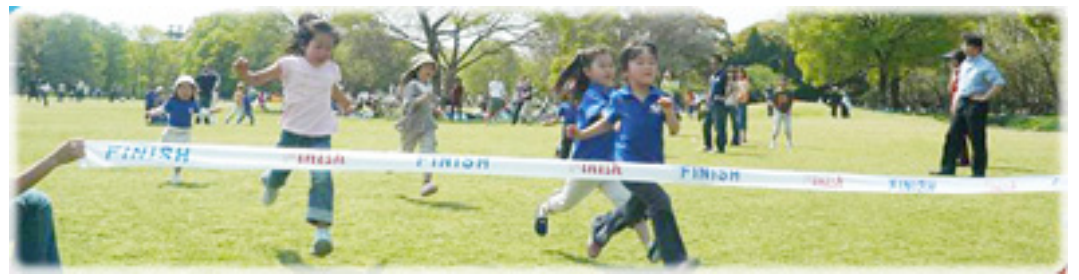

3. ábra: Illusztráció az óvodahálózat honlapján

A honlap számára készült szabadtéri versenyt ábrázoló fotó esetén jól kivehető, hogy a verseny, hajtás fontos Japánban, de nem a győzelem a cél, csupán a részvétel.

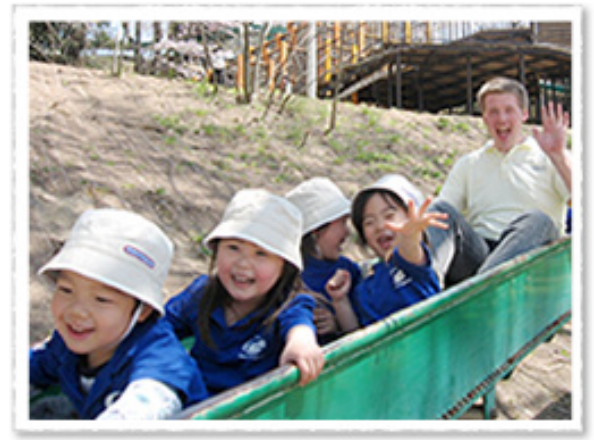

4. ábra: Kirándulási illusztráció az óvodahálózat honlapján 
Az éves kiránduláson a honlap számára készült fotón az ázsiai gyermekek mögött csúszó szőke óvodapedagógust látjuk, aki férfi és nagyon vidám. A gyermekek arca is boldogságtól sugárzik. A kép célja, hogy bemutassa: itt boldog, önfeledt játékban van része a gyermekeknek angol tanulás közben.

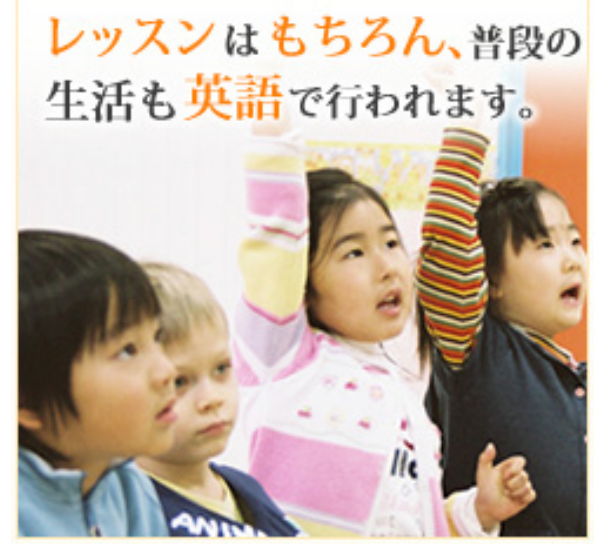

5. ábra: Órai illusztráció az óvodahálózat honlapján

Egy PR-marketing célú, a potenciális vevőket jelentő szülők számára készült fotó, melyet felirat egészít ki az alábbi tartalommal: A lecke, ahogy vártuk, nagyon érdekes, a gyermekek angolul beszélnek. Látszik tekintetükön a bevonódás, átélés és a jelentkezésből adódó izgatottság. Érdekes, hogy az egyetlen nem ázsiai gyermek a képen unottan néz.

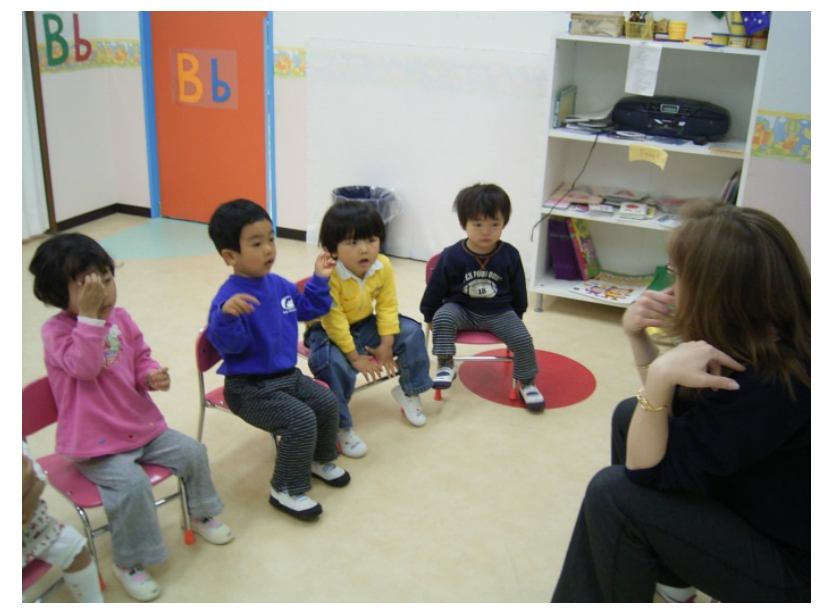

6. ábra: Circle time illusztráció az óvodahálózat szülői katalógusában

Szülök számára készült fotó egy Circle time foglalkozásról, a két éves gyermekek figyelemmel kísérik az óvónőt, egyikük utánozni próbálja. A háttérben a heti $B$ betü látható.

\section{Magyarország mint a játszóházak paradicsoma}

A tanulmány további részében igyekszem áttekinteni az árnyékoktatás gyöngyszemeiként említhető játszóházakat. Milyen típusok vannak, milyen foglalkozásokat tartanak, és bemutatom az általam tartott angol nyelvi kóstolgató foglalkozást, melyet három éve vezetek egy zuglói játszóházban. 
Igen népszerüek a játszóházak hazánkban, szinte minden „sarkon” van már egy. A gomba módra szaporodó játszóházakban általában magyar anyanyelvű tanárok mondókáznak a picikkel. Sok müvelődési házban is hozzáférhető az angol, de itt szinte minden esetben magyar anyanyelvű tanár van, aki sokszor az órát is magyarul tartja, csupán a dalocskák hangzanak el angolul. A Helen Doron program azért lehet népszerübb, mert olcsóbb, mint a nemzetközi vagy kétnyelvű óvodák - ezekben az intézményekben sokszor akár havi $150000 \mathrm{Ft}$-ot is elkérnek tandíjra - nem tölti ki a gyermek teljes aktív idejét, csak különóra, valamint már három hónapos kortól lehet járni az angol foglalkozásokra. Ennek ellenére számos általam megkérdezett iskola csak fél éves kortól javasolja az angol tanítás megkezdését. További ok a népszerüségre, hogy az iskolák viszonylag kicsik (30-70 diák/ iskola, kb. 2500 diák az egész országban) és könnyű találni a lakóhelyhez közeli foglalkozást (Endrődy, 2007b. 24. o.).

A 15/1998. számú NM (lásd elsődleges források) rendelet értelmében alternatív napközbeni ellátás: „....valamely gyermekekből álló célcsoport életkori sajátosságaihoz, illetve a szülők speciális élethelyzetéhez igazodó, a gyermekek társadalmi beilleszkedését és közösségi tevékenységét elösegítő, a helyi szükségleteknek és igényeknek megfelelően változó módon, vagy rendszeres időközönként tematikus program szerint, meghatározott időtartamokra megszervezett, önálló szakmai programban rögzített tevékenység, amelynek biztosítása során kiemelt figyelmet kell tulajdonítani a szocializációnak, a korai, egyéni és csoportos fejlesztésnek, a prevenciónak" (51/A. $\S$ (2)15/1998.NM). Ebbe a tág fogalmi kategóriába érthető a játszóház is, melyről 3 pont rendelkezik az 51/A § 5-7. bekezdése, ebben egyértelműen leszögezik, hogy a játszóház a szülö-gyermek együttes részvételével tart fejlesztő foglalkozásokat. Ezen túlmenően pontos gyermekjóléti, oktatási, nevelési tevékenységet érintő szabályozás nincs. A játszóházak így a gazdasági tevékenységük miatt ugyanolyan szabályozási keretek közé esnek, mint bármely szolgáltató. Ha ételt is adnak a gyermekeknek, akkor az erre vonatkozó szabályozást ugyanúgy be kell tartaniuk, mint a hideg-meleg konyhával rendelkező szolgáltatóknak. Talán a jövőben érdemes lenne meghatározni néhány alapvető feltételt, legalább arra vonatkozóan, hogy ki tarthat foglalkozásokat a játszóházakban, mivel mostani tapasztalataim szerint nem feltétlenül pedagógus végzettségű szakembereket foglalkoztatnak.

Rövid kutatást végezve úgy látom, hogy jelenleg itthon négyfajta játszóház müködik, én így tipizálom őket:

1. Plázás: Kimondottan a nagy motorikus mozgást fejlesztő „golyós” kikapcsolódást nyújtó zárt téri játszótér, föleg áruházakban, plázákban.

2. Önálló: Kisebb-nagyobb tanteremszerủen berendezett helyiség, melyben kisgyermekeknek és/vagy szülőknek is szóló foglalkozásokat tartanak.

3. Kulturális: Népi, zenei vagy egyéb kulturális foglalkozások ad-hoc vagy rendszeres jelleggel, főként kulturális intézmények szervezésében.

4. Képességfejlesztő: Kimondottan a képességfejlesztésre fókuszáló szolgáltató.

Természetesen a formák nem feltétlenül jelentkeznek vegytisztán, vannak hibrid megoldások is. (A jövőben célom egy empirikus kutatás keretében felmérni a játszóházak magyarországi helyzetét, számát, foglalkozási típusait, így az én tapasztalataim csupán hipotézisek a jelenlegi fázisban, ám a tanulmány további folytatásához a fogalmak tisztázását nélkülözhetetlennek éreztem.)

Amellett, hogy a játékosság a legfontosabb, ezekben az intézményekben a fejlesztésre is nagy hangsúlyt fektetnek. Én például előszeretettel alkalmazom a ritmusérzék, mozgás és vizuális igényesség fejlesztését célzó játékokat. Nézzük ezt a példát módszertani ötletekkel! 
A játszóházi foglalkozásoknak nagyon fontos elemei, sőt alappillérei a rítus és ritmus. A gyermekek a minden alkalommal ismétlődő mondókákból tájékozódhatnak, hogy mi a teendőjük. PI. „Clean-up, clean-up everybody everywhere, Clean-up, cleanup everybody do your share!" - ezt a dalocskát éneklem minden olyan alkalommal, mikor azt szeretném, hogy a gyermekek is segítsenek elpakolni az eszközöket. A foglalkozást keretezi egy ugyanarra a dallamra épülő köszöntő és búcsúzó ének. Az elején:

„Hello my friends, how are you, Hello my friends, how are you, Hello my friends, how are you, Nice to see you again."

A végén:

„Good bye friends it was fun, Good bye friends it was fun, Good bye friends it was fun, Hope to see you again."

A keretes jelleg segít a gyermekeknek felismerni, hogy a teremben csak angol nyelvű kommunikáció megengedett. Természetesen ez alól kivételt képeznek a vészhelyzetek. (Mivel a foglalkozások pénteken este vannak, nagyon sok gyermek végtelenül fáradt, ezért kiemelten kell figyelni a biztonságra, különösen a mozgásos feladatoknál.)

A köszöntő után circle time következik, ahol alapvető kommunikációs formákat gyakorlunk, valamint ilyenkor beszélgetünk a havonként változó témákról. Például Animals, Transportation, Seasons. Minden alkalommal minden gyermeknek be kell mutatkoznia, megmondani hány éves, illetve megbeszéljük, ki hogy van, milyen az idő, milyen évszak van. Fontos, hogy ne kérdezzük meg egymás után a hogy vagy és hány éves vagy kérdéseket, mert könnyen keverhetik.

Ezután rövid bemelegítést tartunk, majd könnyed gimnasztikát, vagy egy-két angol dalocskára táncolunk, körjátékozunk pl. Hokey-pokey, Ring around the Rosy, London bridge. Ezután akadálypályán játszunk vagy ernyőzünk. Itt a vezényszavak elsajátításán túl lehetőség nyílik igék tanulására, illetve a színek és számok gyakorlására, például akkor léphetnek a következő korongra, ha megmondják, milyen színü.

A nagy motorikus mozgás fejlesztése után a gyermekek kifáradnak, le kell ülni velük, így ilyenkor olvasni és az adott könyvet értelmezve beszélgetni szoktunk. Az olvasást is mindig egy mondóka vezeti be:

"It's time to read a book,

It's time to read a book,

1,2,3, Listen! Listen!

The title of the book is:..."

Minden évben tartunk Halloween és Christmas-partikat, valamint az európai, amerikai és brit gyermekirodalom klasszikus és mai gyöngyszemeit is igyekszem megismertetni a gyermekekkel, mint pl. Beatrix Potter, Eric Carle vagy Lucy Cousins munkáit. A könyvek mindig a Topichoz, vagy az adott partihoz kapcsolhatóak. Sok esetben kis motorikus mozgásfejlesztő mondókák, vagy vizuális foglalkozás következik. Az olvasást szintén egy mondóka vezeti be, melyet mindenki felismer, tudja, hogy le kell ülni. Mivel a foglalkozások 45 percesek, ezután már csak egy rövid zenés blokkra vagy egy rövid ismétlőjátékra van idő, ezt követően a búcsúzó dal következik. 
Röviden össze kívánom foglalni a foglalkozásokkal kapcsolatos módszertani és szakmai megfigyeléseimet:

- A 45 perc túl hosszú a fáradt gyermekeknek, a 40. perctől már nagyon nehéz olyan feladatot kitalálni, ami leköti őket. Minden esetben ajánlom, hogy valamiIyen új formában ismételjünk, de mindenképp ismételjünk!

- Mivel a szülők általában jelen vannak a foglalkozásokon, könnyen el tudják sajátítani módszereinket és a feladatokat. A dalokat és körjátékokat kimondottan bevonásukkal sajátíttathatjuk el. A gyermekek is élvezik, ha szüleikkel játszhatnak.

- Sok feladat szülői szemmel unalmasnak tűnhet, hisz ismerjük a korai nyelvelsajátítás tempójának természetét (lásd Kovács Judit kutatásai 2009).

- A szülők közt kialakuló baráti kapcsolatok miatt a szülőket időnként figyelmeztetni kell, hogy ne a foglalkozás közben beszélgessenek. A figyelmeztetés legjobb módja egy szülői felügyeletet, bevonódást igénylő feladat beiktatása.

- A gyermekek a felfokozott izgalmak hatására könnyebben sérülhetnek, mint az óvodában, így a biztonsági intézkedések betartása elsődleges.

- A szülők elvárásai nagyon magasak. Azt szeretnék, ha a gyermek már az első néhány óra után tudna kommunikálni. Ezért érdemes sokszor ismételni az alapvető kommunikációra irányuló kérdéseket, illetve minimum négy egymást követő alkalommal beszélni ugyanarról a témáról (Topic).

- Érdemes immersion módszert alkalmazni, hisz a keretes jelleg segít annak gyors megértésében, hogy angol nyelven lehet csak a tanteremben beszélni. Ha magyar nyelvet is használunk a foglalkozáson, nehezebb a gyermeknek megéreznie, mikor beszélhet magyarul, gyakrabban eshet(ünk) abba a hibába, hogy keverjük a mondatokon belül a két nyelvet.

- Játszóházi foglalkozásaim tulajdonképp a Japánban szerzett tapasztalataim adaptációját jelentik.

\section{Összegzés}

Az idézett brit alaptantervek, valamint japán tapasztalataim jelzik, ahogy már fentebb is említettem, a motiváció és a játékosság fontosságát. Ha egy nyelv csupán kötelező és a 'tankönyv-munkafüzet-nyelvtan' hármasára építő, akkor igen kevés gyermek képes arra, hogy figyelmét a tanulásra összpontosítsa. Ha a motiváció csupán a szülőnek/tanárnak való megfelelni vágyás, tartós, alapos, a mindennapi életben kommunikációs eszközként használható nyelvtanulás nem jöhet létre. Minden gyermeknek pozitív kapcsolatra van szüksége azzal, akitől tanul. Ha egy gyermek biztonságban érzi magát, akkor képes annak elsajátítására, hogy adjon egy esélyt az újabb dolgok megismerésére. Ilyenkor az új dolgokat kalandként, felfedezésként képesek megélni.

Motivációs segédeszközök a diákok számára multikulturális közegben:

- Kulturálisan releváns eszközök használata a tanításban (például angol királynő, tea, gyarmatbirodalom, foci, krikett, double-decker, bobby bemutatása)

- Vizuális segítség: multimédia, képek, gyerekek abból a kultúrkörböl (például nem csak fehér gyerek van az iskolában, hanem fekete vagy ázsiai is legyen)

- Dráma: szerepjáték, imitálás, utánzás

- Beszélgetés a szülőkkel esetleges saját élményekről, mely ahhoz a nyelvhez köti őket (például a család angol, ausztrál barátja)

- Együttmúködést segítő feladatok (angol nyelven)

- Angol nyelven beszélő vendégek meghívása (nem feltétlenül anyanyelvi)

- Szókincsfejlesztés: képekkel, kártyákkal, játékokkal

- ICT bevonása

- Modellezés, utánzás

- Olvasás a második nyelven (kérdésekkel segíteni a memorizálást)

- Írás (tanári bemutató, hangos gondolkodás) 
- Nyelvtan explicit elmagyarázása, a struktúra megismertetése, szabályok (itt a magyarázaton van a hangsúly, kíváncsivá kell tenni a diákot, lényeg, hogy kérdezzen)

Ha nem vesszük figyelembe ezeket a lehetőségeket, akkor a következő körforgás alakulhat ki, melyből igen nehéz kilépni (2. ábra):

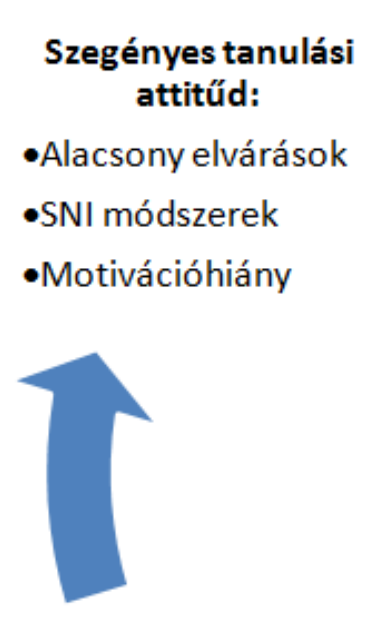

Családi körülmények:

-Szegényes

szocializáció

-Kevés dicséret

•,Vándorlás"

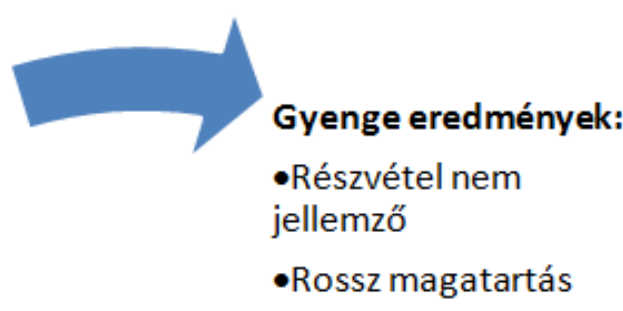

Munkanélküliség:

-Segélyek

-Szegénység

-Depresszió

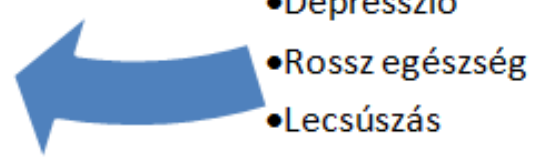

7. ábra: A szegényes tanulási attitűd lehetséges következményei (Endrődy, 2010. 25. o.)

Saját tapasztalataimból kiemelném a Circle time (a Freinet-féle beszélgetőkör továbbfejlesztése) fogalmát, melynek bevezetését minden nyelvből javasolnám az idegen nyelvi kommunikáció, illetve a multikulturális nevelés elősegítésére. Ez nem más, mint az óra elején rövid oldott hangulatú beszélgetés, beszélgetve tanítás. Tipikus témák: közérzet, érzelmek, bemutatkozás, formák, színek, hónapok, számok, időjárás. Mindezt játékos formában, erőteljes gesztusokkal. Ilyenkor lehet a már fent említett beszélgetést is lebonyolítani anyanyelviekkel, vagy más angolul jól beszélő külföldi vendéggel, aki például hazájáról mesél, és lehet kérdezgetni.

Hazánkban még mindig kevés az anyanyelvi szinten beszélő angoltanár és a 21. századi két- vagy többnyelvűségre nevelés igényének megfelelni tudó munkaerő. A kéttannyelvű tanító- és kétnyelvű óvodapedagógus-képzés szélesebb körű képzési lehetőségei mellett a BA-szintű nem kétnyelvü pedagógusképzés törzsanyagába is be kellene építeni bizonyos korai nyelvoktatással kapcsolatos evidenciákat. Fontos lenne az is, hogy a jövőben az általános iskolai tanítók/tanárok is játékos órákat tartsanak. Így mind több gyermeknek lenne kedve az angolt vagy más idegen nyelvet elsajátítani. Fontos lenne, hogy a nyelvtanulás ne csupán kötelesség legyen, hanem egy tetszetős, másfajta kulturális közeg korai megismerési lehetősége és elfogadtatása. 


\section{Felhasznált irodalom}

Bray, M. (2013): Benefits and tensions of shadow education: comparative perspectives on the roles and impact of private supple mentary tutoring in the lives of Hong Kong students. Journal of International and Comparative Education, 2/1, 18-30.

De Houwer, A. (2009): Bilingual First Language Acquisition. Channel View Publications Ltd/ Multilingual Matters, Bristol.

Doi, T. (1981): The anatomy of dependence - The key analysis of Japanese behavior. Kodansha international, Tokyo.

Depaepe, M. \& Henkens, B. (2000): The history of education and the challenge of the visual. Paedagogica historica, 36. 1., 11-17.

Endrődy Orsolya (2007a): Japánban jártam - Az óvoda szerepe: fegyelmezni. Óvodai élet, 15. 2. sz., 11-12. Commitment Kommunikációs Iroda Kft., Budapest.

Endrődy Orsolya (2007b): A magyar nyelvoktatási piac felmérése az Brit Nagykövetség kérésére. Kézirat.

Endrődy-Nagy Orsolya (2010): Esélyegyenlőség és differenciálás koragyermekkorban. Elvek és gyakorlat Nagy-Britanniában. In: Kardos Anita és Kármán Tímea (szerk.), Apróságok nagy kalandjai. Óvodák a Comenius programban. (= HOPPÁ Disszeminációs füzetek 27.) Tempus közalapítvány, Budapest, 24-26.

URL: www.tpf.hu/pages/books/index.php?page_id=35\&books_id=228

Endrődy-Nagy, Orsolya (2011): Childhood in Japan - Teaching ESL in a Japanese International Preschool. In: Zelényi Annamária és Zsibók Anita (szerk.), Lingua. „Szaknyelvoktatás és multikulturalitás", 2011. április 28-29. BCE INYOK Alkalmazott Nyelvészeti Kutató- és Továbbképző Központ, Budapest, 230-242.

Fujikane, H. (2006): Globális oktatás az Egyesült Államokban, az Egyesült Királyságban és Japánban. In: M. Bray \& P. Tóth (szerk.), Összehasonlitó pedagógia: Folytatódó hagyományok, új kihívások és új paradigmák. Magyar Pedagógiai Társaság, Budapest, 135-150.

Győri Gordon János (2009): Az oktatás harmadik átfogó reformja Japánban. OFI Tudástár. URL: www.ofi.hu/tudastar/oktatas-harmadik-atfogo\#1, letöltés ideje: 2013. június 25.

Kitzinger Arianna (2009): Bevándorlás, többnyelvűség és identitás Finnországban. In: Kovács Judit és Márkus Éva (szerk.), Kéttannyelvüség - Pedagógusképzés, kutatás, oktatás. ELTE Eötvös Kiadó, Budapest, 187-198.

Kovács Judit (2009): Magyar-angol kéttannyelvű tanító- és óvópedagógus-képzés az ELTE Tanítóés Óvóképző Főiskolai Karán. In: Kovács Judit és Márkus Éva (szerk.), Kéttannyelvüség Pedagógusképzés, kutatás, oktatás. ELTE Eötvös Kiadó, Budapest, 41-52.

Márkus Éva (2009): Az ELTE TÓFK magyar-német kéttannyelvű tanító- és óvodapedagógus képzési programjai. In: Kovács Judit és Márkus Éva (szerk.), Kéttannyelvüség - Pedagógusképzés, kutatás, oktatás. ELTE Eötvös Kiadó, Budapest, 53-70.

Mietzner, U. \& Pilarczyk, U. (2005): Methods of Image Analysis in Research in Educational and Social Sciences. In U. Mietzner \& K. Myers \& N. Peim (szerk.), Visual History, Images of Education. Peter Lang AG, European Academic Publishers, Bern, 109-129.

Nikolov, Marianne (2004): Az életkor szerepe a nyelvtanulásban. Modern Nyelvoktatás, 10. 1. sz., 3-26. Budapest: Corvina.

Numata, H. (2006): Amit a gyerekek az oktatás modernizációjával veszítettek: a nyugateurópai és a kelet-ázsiai tapasztalatok összehasonlítása. In M. Bray \& P. Tóth (szerk.), Összehasonlító pedagógia: Folytatódó hagyományok, új kihívások és új paradigmák. Magyar Pedagógiai Társaság, Budapest, 241-267.

Seliger H. \& Krashen, S. \& Ladefoged, P. (1975): Maturational constraints in the acquisition of a native-like accent in second language learning. Language Sciences, 36. 209-231.

Sontag S. (2007): A fényképezésröl. Európa Könyvkiadó, Budapest.

Tobin J. \& Hsueh, Y. \& Karasawa, M. (2009): Preschool in Three Cultures Revisited. The University of Chicago Press, Chicago-London.

Trentinné Benkő Éva (2009): Az ideális kéttannyelvű tanár. In Kovács Judit és Márkus Éva (szerk.), Kéttannyelvüség - Pedagógusképzés, kutatás, oktatás. ELTE Eötvös Kiadó, Budapest, 143-159.

Vágó Irén és Vass Vilmos (2006): Az oktatás tartalma: 5.3.1. Idegen nyelv. In G. Halász \& J. Lannert (szerk.), Jelentés a magyar közoktatásról. OKI, Budapest, 240-253. 


\section{Elsődleges források}

Primary National Strategy, Supporting children learning English as an additional language (2007): Department for Children, Schools and Families, London.

The Early Years Foundation Stage (2007): Department for Education and Skills, London.

15/1998. (IV. 30.) NM rendelet, a személyes gondoskodást nyújtó gyermekjóléti, gyermekvédelmi intézmények, valamint személyek szakmai feladatairól és működésük feltételeiröl (2013.07.01 hatályos állapot).

URL: http://net.jogtar.hu/jr/gen/hjegy_doc.cgi?docid=99800015.NM\&timeshift=1

Blue dolphins International Preschool honlapja

URL: www.blue-dolphins.net, letöltés ideje: 2013. június 26. 


\section{Mellékletek}

\section{1. sz. melléklet}

\section{Step Teaching Method!!!}

When teaching anything (not just language) you should also start easy and gradually get more challenging... When it comes to learning a foreign language, SS can understand a long time before they can speak.

In general a target language "theme" (eg "colors"; "animals"; "numbers"; "actions" etc...) will take about 4 weeks to "teach". To teach each target language, follow this sequence:

$$
\text { INTRODUCTION } \Rightarrow \text { UNDERSTANDING } \Rightarrow \text { SPEAKING }
$$

INTRODUCTION: Introduce target language/ flashcards and "listen and repeat" as a class. At least at this stage, don't single out individual SS to repeat things. The introduction stage is NOT a challenging stage!! Don't test your SS yet!! Let your SS feel comfortable with the new language at their own pace. Any pressure on your SS in the introduction stage will have an opposite effect.

UNDERSTANDING: This is a very important phase because it's a big step to go from "listening and repeating" to "speaking". After we have introduced the language a bit we can start to challenge their understanding. NB repeating is not necessarily understanding!!! many SS can sing songs perfectly but if you ask them what the words mean they have no idea, and they certainly can't actually use those words to do anything in English.... At the "understanding" stage of the 3-step method, the SS stop just repeating and are actually asked to use English to do some task. The key ingredient of the "understanding" phase is that the SS (1) hear language and (2) respond somehow (usually physically) depending on whether they understood the language or not... For example: Teacher shows 6 color cards and says "touch red". If the SS understood correctly they will touch the red card. But remember, at this stage they do not need to speak!!!. If you challenge their understanding, and give them lots of praise when they are successful, they will start to speak naturally!!! When that happens it's time to move to the next step:

SPEAKING: when understanding becomes easy for your students, start to challenge their speaking... When you plan your lessons you must decide when the SS are ready to move on to each phase. If your SS are still not really understanding the language, DON'T move on to speaking games!!! The best time to decide this is soon after each lesson has finished!!! 


\section{2. sz. melléklet}

\section{Goals for Star Fish class}

First Semester

\section{Handwriting skills}

Fine motor skills development
Eye/hand coordination

Eye/hand coordination

Forming vertical lines

Forming horizontal lines

Forming shapes - circle, square, triangle,

Practice printing name. - Make tracing sheets,

\section{Colors, shapes, numbers and letters}

Distinguishing color - red, blue, yellow, green,

Letter recognition A - H

Letter order $\mathrm{A}-\mathrm{H}$

Matching numbers $1-5$
Matching colors and shapes

\section{Counting and math skills}

Counting from $1-5$

Reading Readiness

Following directions

Visual discrimination

flash cards and picture dictionary, My first word book. And other teaching tools

Phonics

位

Communication Skills

Communication Skills

Children understanding and following through with directions ( stand up, sit down, listen, repeat after me
get your diaper,

Evaluation date will be the week of
One on one with mother and or father will be up to each individual school 